Journal of Applied Animal Welfare Science

\title{
Consumer Attitudes Toward Animal Welfare- Friendly Products and Willingness to Pay: Exploration of Mexican Market Segments
}

Genaro C. Miranda-de la Lama, Laura X. Estévez-Moreno, Morris Villarroel, Adolfo A. Rayas-Amor, Gustavo A. María \& Wilmer S. Sepúlveda

To cite this article: Genaro C. Miranda-de la Lama, Laura X. Estévez-Moreno, Morris Villarroel, Adolfo A. Rayas-Amor, Gustavo A. María \& Wilmer S. Sepúlveda (2018): Consumer Attitudes Toward Animal Welfare-Friendly Products and Willingness to Pay: Exploration of Mexican Market Segments, Journal of Applied Animal Welfare Science, DOI: 10.1080/10888705.2018.1456925

To link to this article: https://doi.org/10.1080/10888705.2018.1456925

Published online: 03 Apr 2018.

Submit your article to this journal $₫$

Lll Article views: 15

Q View related articles 두

View Crossmark data $ऍ$

Full Terms \& Conditions of access and use can be found at http://www.tandfonline.com/action/journallnformation?journalCode=haaw20 


\title{
Consumer Attitudes Toward Animal Welfare-Friendly Products and Willingness to Pay: Exploration of Mexican Market Segments
}

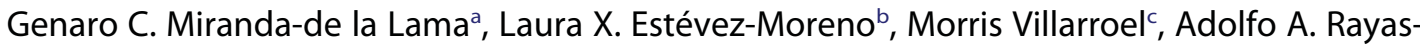 \\ Amor $^{a}$, Gustavo A. María ${ }^{\text {, }}$ and Wilmer S. Sepúlveda ${ }^{e}$

\begin{abstract}
aDepartment of Food Science, Metropolitan Autonomous University, Lerma, State of Mexico, Mexico; 'bnstitute of Agricultural and Rural Sciences, University Autonomous of State of Mexico, Toluca, Mexico; 'Department of Animal Science, Higher Technical School of Agricultural Engineering (ETSIA), Polytechnic University of Madrid, Madrid, Spain; 'Department of Animal Production and Food Science, Faculty of Veterinary Science, University of Zaragoza, Zaragoza, Spain; 'Group of Research and Enterprise and Regional Productivity (IPER), Faculty of Economics, Management and Accounting Sciences, Universidad Libre, Campus Majavita, Santander, Colombia
\end{abstract}

\begin{abstract}
The study aim was to identify consumer segmentation based on nonhuman animal welfare (AW) attitudes and their relationship with demographic features and willingness to pay (WTP) for welfare-friendly products (WFP) in Mexico. Personal interviews were conducted with 843 Mexican consumers who stated they purchased most of the animal products in their home. Respondents were selected using a quota sampling method with age, gender, education, and origin as quota control variables. The multivariate analysis suggested there were three clusters or consumer profiles labeled "skeptical," "concerned," and "ethical," which helped explain the association between AW attitudes, some demographic variables, and WTP for WFP. This study is one of the first to address consumer profiling in Latin America, and the findings could have implications for the commercialization of WFP. Hence, customers should receive information to consider welfare innovations when deciding to purchase animal products. The growth of the WFP food market establishes an element of a far more multifaceted phenomenon of sustainable consumption and support of a new paradigm called responsible marketing in emerging markets such as Mexico.
\end{abstract}

\section{KEYWORDS}

Animal welfare;

consumer segmentation; welfare-friendly products; emerging markets; Mexico

Globalization, growing incomes, urbanization, and migration are leading factors in changing consumption behavior toward food products in many developed and developing countries (Zhllima, Imami, \& Canavari, 2015). The majority of the increased demand will occur in emerging markets in Asia, Africa, and Latin America, especially in the so-called middle-class urban population (Scholten, De Boer, Gremmen, \& Lokhorst, 2013). During the last decade, many Latin American emerging economies such as Brazil and Mexico have also established themselves as major players in global food production (Popkin, 2014). Rising incomes, ruralurban migration, an increase in tertiary activities, exposure to international lifestyles and media, access to frequently updated information and telecommunication technologies, and the willingness to pay (WTP) more for differentiated quality nonhuman animal food products are all stimulating consumer segmentation in these markets (Javalgi \& Grossman, 2016). Hence, it is paramount for governments and businesses in emerging economies (especially global, multinational, and exporting food companies) to understand consumer segmentation based on

CONTACT Genaro C. Miranda-de la Lama g.miranda@correo.ler.uam.mx Departamento de Ciencias de la Alimentación, División de Ciencias Biológicas y de la Salud, Universidad Autónoma Metropolitana, UAM-Lerma, Av. Hidalgo Poniente 46, 52006, Lerma de Villada, Estado de México, México.

๑) 2018 Informa UK Limited, trading as Taylor \& Francis Group 
purchasing decisions and to compare how they might differ from those in developed countries (Thøgersen, De Barcellos, Perin, \& Zhou, 2015).

The welfare of nonhuman animals on farms is a heavily debated topic in both society and academic literature (Mulder \& Zomer, 2017). This debate has resulted from the increasing degree of industrialization in animal production, food safety concerns, socioethical considerations, animal abuse scandals (especially hidden-camera investigations), humans' bonds with companion animals, and most likely from the increasing knowledge about the physiological and emotional states of animals (Robbins, Franks, Weary, \& von Keyserlingk, 2016). As a result, animal welfare (AW) crises (i.e., livestock lorry accidents, long-distance transport, or cruelty at abattoirs) can have important effects in the media and degrade the image of the agrifood industry for consumers (Miranda-de la Lama, Sepúlveda, Villarroel, \& María, 2011).

The potential conflicts between AW and efficient farming can often be resolved (or at least reduced) through demonstration of how improving AW can provide financial benefits for society, farmers, and the agrifood industry (Dawkins, 2017). Latin American farmers support efforts to improve the welfare of farm animals if those efforts improve the quality and quantity of products and allow access to higher-priced international markets, rather than just improving efforts for ethical reasons (Gallo \& Huertas, 2016). Nevertheless, recent scientific evidence in the region (specially in Mexico, Chile and Brazil) has indicated growing social concern in terms of AW issues and their ethical, sociological, and political implications (Vargas-BelloPérez, Miranda-de la Lama, Teixeira, Enríquez-Hidalgo, Tadich, \& Lensink, 2017, as in other parts of the world (i.e., Di Pasquale et al., 2016; Sato, Hötzel, \& von Keyserlingk, 2017).

Mexico has been slow to update its legal regulations on AW, which include some guidelines on animal transport, stunning, and slaughter throughout the preslaughter logistic chain (Miranda-de la Lama et al., 2012). However, even with the current economic downturn, Mexican consumers, particularly from the middle, upper-middle, and higher-income stratas (23 million, 16 million, and 6.7 million people, respectively) still purchase high-quality animal products such as meat, eggs, and milk. The motivation to purchase these products with enhanced AW attributes is closely related to consumers' demographic features, their knowledge of AW issues, and their trust in information about rearing systems and attitudes (Miranda-de la Lama et al., 2017).

Consumers' attitudes involve the psychological processes they go through in recognizing needs and finding ways to address these needs, collecting and interpreting information, making plans and implementing these plans, and making purchase decisions and exhibiting postpurchase behavior (Basha, Mason, Shamsudin, Hussain, \& Salem, 2015). Food choices tend to be stable over time; they do not change fast, as consumers are creatures of habit (Gómez-Corona, Escalona-Buendía, García, Chollet, \& Valentin, 2016). However, food purchase habits can evolve, and new trends can arise such as animal welfare-friendly products (WFP). One important objective of consumer psychology is to be able to persuade consumers and change their attitudes. In this context, the prerequisite for changing an attitude is to determine the psychological need served by the attitude (Grewal, Mehta, \& Kardes, 2000). A change of habit involves a change of attitudes toward a product. One question is whether consumers in Latin American emerging countries such as Mexico perceive AW standards as an added value of the product.

To gain an understanding of consumer segmentation in an emerging market, it is important to tackle it from an academic research perspective and in relation to the practical implications such as international trade and national food marketing strategies. The estimation of consumer WTP for WFP has received significant research attention in developed economy markets, but much less is known about emerging economies such as Mexico. Therefore, the aim of the current study was to identify consumer segmentation based on AW attitudes and their relationship with demographic features and WTP for WFP in Mexico. 


\section{Materials and methods}

The study was carried out in the Toluca Metropolitan Valley (TMV, including 22 municipalities) from May 2015 to June 2015 . The TMV is a densely populated $\left(>905\right.$ inhabitants $\left./ \mathrm{km}^{2}\right)$ area in the State of Mexico with a surface area of $2669.8 \mathrm{~km}^{2}$ (COESPO,2015; State of Mexico Population Council) and a population of 2,415,277, making it the fifth most populous metropolitan area in the country (INEGI, 2011; National Institute of Statistics and Geography). The TMV was selected because food market researchers, food marketers, and consulting companies widely use this city for research as its sociodemographic profile is representative of the Mexican Census of Population (Miranda-de la Lama et al., 2017).

\section{Study description}

Personal interviews were conducted with 843 consumers who stated they purchased most of the animal food products in their home. Respondents were selected using a quota sampling method with age, gender, education, and origin (rural or urban) as quota control variables. The consumers who accepted the survey (the rejection rate was 3.4\% compared with the total of the sample) and passed the inclusion criteria (to consume meat, eggs, and milk) took part in the study. Consumers were surveyed at eight supermarket chains that sold animal food products. The consumer interviews were conducted individually at the animal food section of the supermarket (buying context).

As in developed countries, supermarkets have displaced local food shops and represented $60 \%$ of the sales in products of animal origin in 2013 to 2014 (Gasca \& Torres, 2014). The features of the sample with respect to the quota control variables are presented in Table 1 . Women were slightly oversampled (55.9\%) compared with the sex proportions from the national 2010 census $(51.2 \%$ women; INEGI, 2011). However, this oversampling was judged to be reasonable in food-related consumer research because women normally outrepresent men as those responsible for food purchases within the household (Verbeke \& Viaene, 1999).

\section{Questionnaire and measurement scales}

A questionnaire was drawn up following a Likert-type scale AW attitude assessment model (Mazas, Fernández-Manzanal, Zarza, \& María, 2013). A sample of 84 consumers was used to validate the scale, which showed acceptable internal reliability and a Cronbach's alpha value of .66. The selected topics were based on a literature review and the researchers' own experience. The topics covered feelings, emotions, and issues related to legislation, commerce, and WTP for WFP. The structure of the questionnaire was similar to the one used by the European Food Safety Authority (EFSA,2007) in its Survey of Attitudes of European Union (EU) Citizens toward Animal Welfare. The questions began with the statement, "Do you think that ..." and were measured as a set using an ordinal scale with 5 points $(1=$ definitely not, $2=$ probably not, $3=$ it does not matter to me, $4=$ probably yes, and 5 = definitely yes).

The survey included six sections of questions, and the average survey completion time was 15 minutes. The first section regarded the importance of farm AW. In the second section,

Table 1. Demographic features of participants included in the study, expressed as a percentage $(N=843)$.

\begin{tabular}{lccllc}
\hline Demographic & & $\%$ & Demographic & & $\%$ \\
\hline Gender & Male & 55.9 & Origin & Urban & 59.1 \\
& Female & 44.1 & & Rural & 40.9 \\
Age (years) & $18-30$ & 31.4 & Education level & Elementary school & 10.7 \\
& $31-45$ & 34.2 & & Junior high school & 25.4 \\
& $46-60$ & 23.6 & & High school & 34.3 \\
& $>60$ & 10.8 & & Higher education & 29.7 \\
\hline
\end{tabular}


participants were asked about their knowledge about AW. The third section covered the need for information about AW. The fourth section concerned general attitudes about current AW conditions in Mexico. In the fifth section, respondents were asked about how AW attitudes could influence their buying behavior (including their willingness to pay more for WFP) and about their attitudes about compensations for farmers and retailers. The final section concerned specific characteristics of buying behavior (main reasons to buy WFP, customer loyalty, labeling features, and the respondents' concept of quality).

\section{Specifications of the model}

The SPSS (Statistical Package for the Social Sciences) Version 21.0 was used for all statistical analyses. The data were evaluated by multivariate analysis (MVA) with factor and cluster analysis. The factor analysis was used to calculate correlations and summarize the 12 variables related to consumer perceptions toward AW. The factorial analysis is a technique used to reduce and summarize information, and it allowed us to explain the existing relationships between a specific number $p$ of observable variables $\mathrm{X} 1, \mathrm{X} 2, \ldots \mathrm{X} p$. In the factorial analysis model, each observable variable Xi can be explained by $m$ common factors $(m<p)$ and a unique or specific factor of each variable. Thus, all original variables are influenced by all the common factors as long as there is a unique factor for each variable. In this way, we could establish multidimensional correlations among the variables using the common factors.

The factors were obtained using the principal component extraction model. The number of factors to be retained was identified using the criterion of eigenvalues N1. The Kaisere Meyere Olkin Index (KMO) and Bartlett's test of sphericity were used to measure correlations among variables to comply with the initial assumption of correlations. Once the components were extracted, to gain a better understanding of the factors, a varimax method of ortogonal rotation was carried out. Therefore, the factor scores in the analysis were estimated by the regression method (Sepúlveda, Maza, \& Mantecón, 2008) and were used for cluster analysis.

The cluster analysis was carried out to group consumers according to attitudes toward AW. It provided groups of consumers according to internal homogeneity and intragroup heterogeneity criteria. The Euclidian distance was measured by using the square root of squared differences. The distances between objects were calculated from the factor analysis. The Ward method was used as the agglomeration method. Finally, analysis of variance (ANOVA) and chi-squared tests (both the bivariant type) were used to identify the significant variables that allowed for discriminating among clusters.

\section{Results}

The results are organized in two subsections. The first section presents results from factor analysis of the 12 questions related to consumer attitudes toward AW. The second section is focused on cluster analysis using results from factor analyses, demographic features, and WTP for WFP.

\section{Factor analysis}

Four factors were extracted that explained $54.6 \%$ of the total variance, while the KMO was .806 and the Bartlett test $(p=.000)$ suggested a high correlation among variables. The parameters loaded high on the four factors (Table 2). The first factor accounted for $26.40 \%$ of the total variance and was characterized by 3 of the 12 variables used (that farm animals feel pain, have positive or negative emotions, and should be free of fear and stress). This first factor indicated emotional attitudes about AW and was labeled the "sensitivity factor." The second factor accounted for $10.50 \%$ of the total variance and was characterized by 4 of the 12 variables (new laws are required to avoid abuse during handling on the farm; AW should be taught in primary school; farm animals should be well fed, well sheltered, and healthy; and farm 
Table 2. Factorial analysis: Classes of Mexican consumers' attitudes.

\begin{tabular}{|c|c|c|c|c|}
\hline \multirow[b]{2}{*}{ Do you believe that ... } & \multicolumn{4}{|c|}{ Factors } \\
\hline & Sensitivity & Regulation & Commerce & Information \\
\hline -the animals on the farms feel pain? & .77 & & & \\
\hline -the animals on the farms have emotions? & .75 & & & \\
\hline -the animals on the farms should be free of fear and distress? & .64 & & & \\
\hline -new laws are required to avoid abuses during operations in the farms? & & .77 & & \\
\hline -animal welfare should be part of teaching in primary school? & & .60 & & \\
\hline -animals on the farms should be well fed, well sheltered, and healthy? & & .55 & & \\
\hline -farm animals should be able to express the natural behavior of their species? & & .47 & & \\
\hline $\begin{array}{l}\text {-farmers should be economically compensated for increases in production } \\
\text { costs as a result of improvements in animal welfare? }\end{array}$ & & & .69 & \\
\hline $\begin{array}{l}\text {-imported animal foods should be as respectful of animal welfare as the foods } \\
\text { are in Mexico? }\end{array}$ & & & .66 & \\
\hline $\begin{array}{l}\text {-you change your retail store in order to acquire welfare-friendly products (i.e., } \\
\text { organic, ecological)? }\end{array}$ & & & .63 & \\
\hline -in Mexico, there is enough information about animal welfare on the farms? & & & & .80 \\
\hline $\begin{array}{l}\text {-the actual labels on the products of animal origin allow for identification of } \\
\text { conditions in which the animal was raised and animal welfare? }\end{array}$ & & & & .79 \\
\hline Explained variance (\%) & 26.40 & 10.50 & 9.70 & 8.20 \\
\hline
\end{tabular}

animals should be able to express their natural behavior). Because this factor included the concept about the need for appropriate laws, it was labeled as the "regulation factor."

The third factor accounted for $9.70 \%$ of the total variance and was characterized by 3 of the 12 variables (farmers should be compensated for cost increments for improvements in AW, imported foods should be respectful of AW, and whether the respondent would change their retail store to acquire WFP). Because this factor included an economic aspect, it was called the "commerce factor." The fourth factor accounted for the remaining $8.20 \%$ of the total variance and was characterized by 2 of the 12 variables (there is enough information about AW in Mexico and current labels on products of animal origin identify how animals are raised and their AW). Because this factor was related to providing more details about production systems, it was labeled as the "information factor."

\section{Cluster analysis}

The cluster analysis suggested the existence of three clusters or consumer profiles that explained the association between AW attitudes, demographic variables, and WTP for WFP (Table 3 and Figure 1). The four factors corresponding to attitudes toward AW showed differences among groups (ANOVA, $p=.000$ ). Given the associations that were found in each cluster, Cluster 1 was labeled "skeptical," Cluster 2 was labeled "concerned," and Cluster 3 was labeled "ethical," according to the attitudes about AW preferentially used for each profile. The majority (55\%) of the respondents were in Segment 3 (ethical consumers), while 30\% were in Segment 1 (skeptics) and only 15\% were in Segment 3 (concerned). The "skeptical" consumers were respondents who had negative values for the four factors analyzed. They included about the same amount of men and women (14\% difference), people of city or rural origin (18\% difference), an age range of 18 years to 30 years old, with more people with a high school education and a medium level of WTP for WFP products (difference of $32 \%$ ).

The "concerned" consumers had high values of commerce and information factors, were mostly women (32\% difference with men), lived in the city (40\% difference), and were aged 31 years to 45 years old, with high school studies and a high WTP for WFP products (200\% difference). Finally, the "ethical" consumers who had high values of sensitivity and regulation factors were mainly women (33\% difference), lived in cities (63\% difference), and were aged 31 years to 45 years old, with university studies and a high WTP for WFP (169\% difference). Among the demographic variables, the level of study (chi-squared test, $p=.010$ ) was responsible 
Table 3. Consumer segmentation based on attitudes, demographic features, and willingness to pay for welfare-friendly foods in Mexico $(n=843)$.

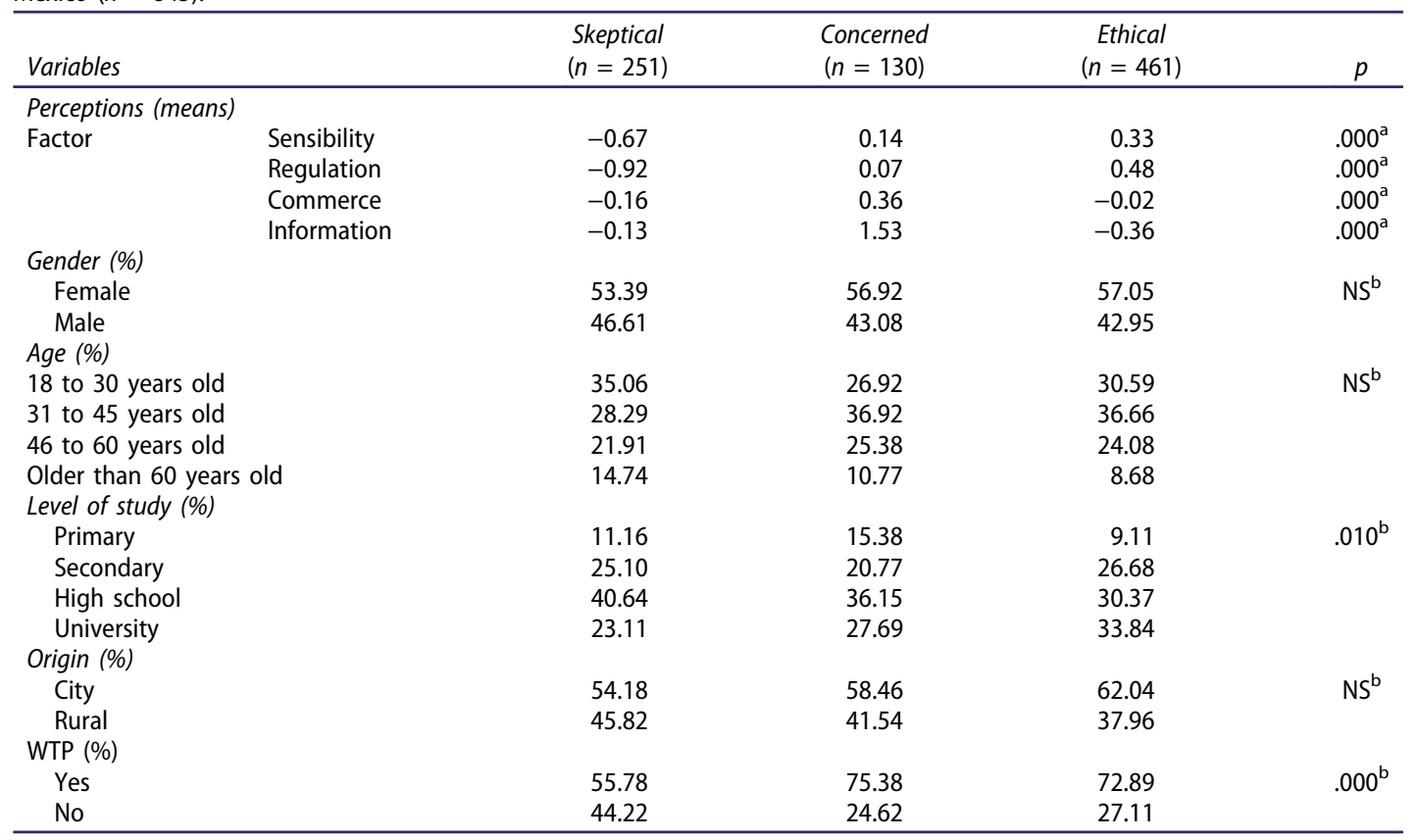

Note. WTP = willingness to pay; NS = not significant.

${ }^{a}$ Analysis of variance.

${ }^{\mathrm{b}}$ Chi-squared test.

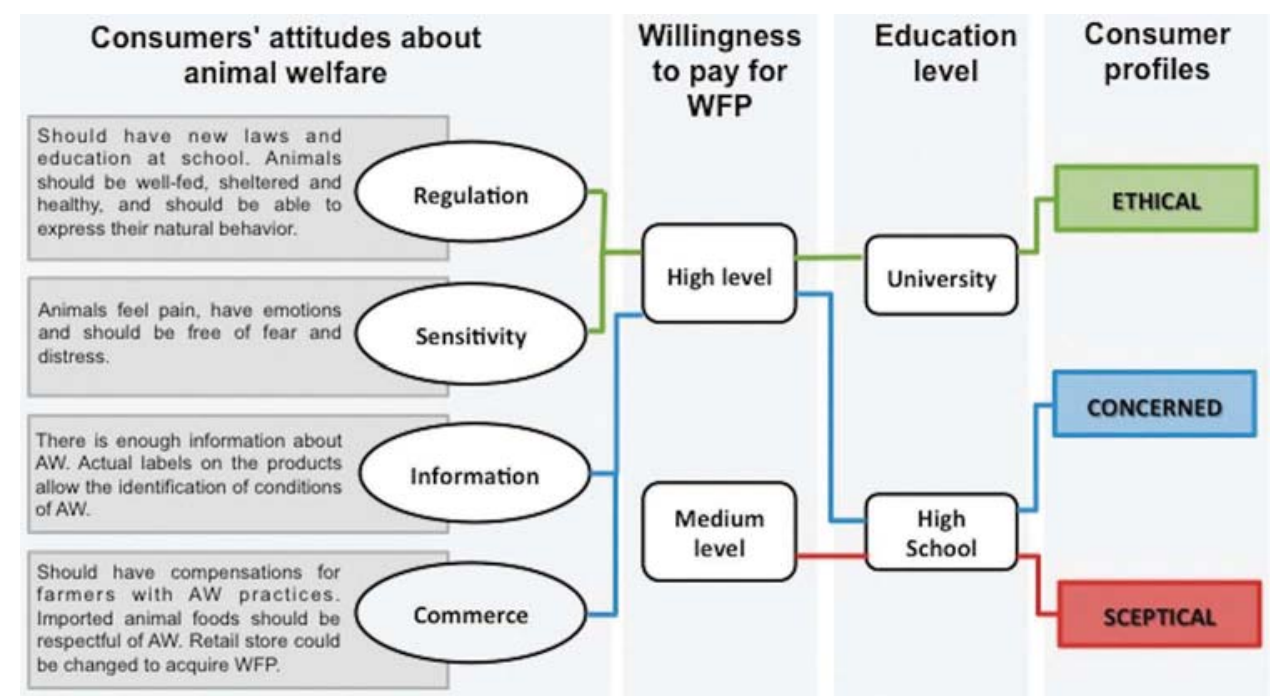

Figure 1. Simplified illustration of the model flow about consumer segments based on animal welfare (AW) attitudes and their relation with demographic features and willingness to pay for welfare-friendly products (WFP) in Mexico $(n=843)$.

for the differences among groups. The effects of gender, age, and origin were not statistically significant. Likewise, there was a relationship between WTP (chi-squared test, $p=.000$ ) and the groups of consumers. 


\section{Discussion}

The goal of the main study was to understand possible consumer segmentation using the associations among AW attitudes, some demographic variables, and WTP for WFP. We know that the habits of consuming meat, milk, and eggs from domestic animals in Mexico originated centuries ago (Spanish conquest of Mexico) and are a strong component of the contemporary Mexican diet. However, the consumption of these animal food products has increased considerably during the last few years as a consequence of diet diversification resulting from rising incomes and new styles of food consumption (Pardío et al., 2012). The MVA suggested there were three clusters or consumer profiles labeled "skeptical," "concerned," and "ethical."

Segmentation entails the classification of consumers into groups that are rather homogenous in one or more key characteristics, such as motivations (Verain, Sijtsema, \& Antonides, 2016). Likewise, level of education had a significant effect on consumer segmentation in all clusters and showed that more educated people are more likely to be willing to promote AW, thereby confirming findings reported for European citizens by Toma, Stott, Revoredo-Giha, and Kupiec-Teahan (2012) and Laroche, Bergeron, and Barbaro-Forleo (2001) in North America. Additionally, WTP for WFP had an important influence on the characterization of each cluster. The market for WFP can be considered a niche market that attracts consumers with a specific profile (Vanhonacker \& Verbeke, 2014).

In many countries, producers, retailers, and other stakeholders in the food chain have recognized that consumer concerns for AW represent a business opportunity that could be profitable if incorporated into their commercial strategies (Velarde \& Dalmau, 2012). The effective marketing of WFP might differentiate a retailer in the marketplace and thereby enhance customer loyalty, sales, and eventually the retailer's profits (Miranda-de la Lama, Sepúlveda, Villarroel, \& María, 2013). Amos and Sullivan (2017) evaluated how 80 of the world's largest food companies are managing AW. They concluded that AW is rising up the business agenda with an increasing number of companies establishing policies and setting objectives and targets. Despite this progress, AW continues to receive much less attention than other corporate responsibility issues.

Furthermore, there are currently no national specific regulations governing the essential requirements for certification of WFP that could meet the higher expectations of Mexican consumers reflected in this study. Although some food industries and supermarket chains have developed voluntary codes of practice and AW standards, our study results suggest that consumer demand for WFP is not always being satisfied. Our study is the first to address consumer profiling in Latin America, and the findings could have implications for the commercialization of WFP.

\section{Skeptical consumers}

Approximately $30 \%$ of the respondents were grouped as "skeptical" consumers (similar ratios of men or women and people of rural or urban origin, with a high school education and aged mostly 18 to 30 years old). This group avoids emotional arguments related to increasing sensitivity for animals and does not demand more regulations to improve AW. They do not want more information or demand commercial mechanisms to promote AW. Our results indicated that this type of consumer is highly critical of their environment and is well informed but skeptical about the sources of information and certification for WFP. Animal welfare often tends to fall under broader voluntary certification schemes (i.e., Global Good Agricultural Practice or Global G.A.P., Rainforest Alliance Certified, EU Organic, and Australian Certified Organic) only aimed at conveying a general message of overall high quality to the consumer, resulting in consumer misinterpretation (Faucitano, Martelli, Nannoni, \& Widowski, 2017). The general profile is reminiscent of one described by Eden, Bear, and Walker (2008) in UK consumers who were skeptical about food assurance systems. Similar findings have been communicated by Harper and Makatouni (2002). 
Among the skeptical consumers, a large proportion were from the millennial generation (35\% were aged 18-30 years old, 28\% were aged 31-45 years old). There has been some debate regarding the exact ages of millennials (born between 1980 and 1995 or between 1982 and 2004; McCormick, 2016), but they are characterized as being heavy users of technology and having access to frequently updated information and telecommunication technologies (Newbold \& Scott, 2017); however, many have had little contact with modern animal production practices (Frank, Oytam, \& Hughes, 2017). They consider themselves to be well informed (Brown \& Vergragt, 2016) and are more self-involved than previous generations (i.e., Generation X, baby boomers; Bergman, Fearrington, Davenport, \& Bergman, 2011). They do not tend to repurchase products or services that do not fulfill their expectations (Barber, Goodman, \& Goh, 2011). They are also picky buyers (Atkin \& Thach, 2012) and are concerned about the environment (Thach \& Olsen, 2006), with some interest in foods with social/ethical or eco-friendly labels (Pomarici \& Vecchio, 2014). Millennials make up 25\% of current consumers, so millennial attitudes may be a significant predictor of future food choices and may drive changes in the food landscape (Young \& McCoy, 2016).

Surprisingly, despite their possible skepticism regarding AW and its emotional, legal, market, and media impacts, skeptical consumers demonstrated an average interest (around 55\%) in paying more for WFP. Thus, their skepticism could be more related to poor communication and a lack of confidence in the government and/or the Mexican food industry than any possible preoccupation about AW. Most likely, their skepticism was more related to the current environment in a country undergoing social and security crises. In that context, a key way to reach these consumers in Mexico is for AW laws and certification systems to be transparent, reliable, and comparable internationally.

Those characteristics may be best demonstrated with labels that inform about certification for WFP and by avoiding fictitious advertising from manufacturers that occurs with some products labeled as ecological and WFP (i.e., eggs and milk) but that do not have recognized certifications. In agreement with this hypothesis, Harper and Makatouni (2002) concluded that a lack of trust in sources of information, especially the government and the food industry, was identified as a key barrier to purchasing WFP.

Information on the label is one of the attributes that consumers value most when buying a food product (Sepúlveda et al., 2008). However, the effectiveness of a label depends on how the information is presented and on the ability of the consumer to absorb and act on it (Teisl, Rubin, \& Noblet, 2008). Therefore, sustainability labels and eco-labels may be comparable to WFP labels, which have succeeded on the market if they are able to transform environmental friendliness from a credence attribute to a search attribute about AW (Di Pasquale et al., 2016; Grolleau \& Caswell, 2006). The proportion of consumers with no clear position about WFP was important, and so they should be considered and monitored when developing information strategies on this topic for society at large.

\section{Concerned consumers}

Animal welfare involves societal and human values, ethical concerns, and moral considerations because it incorporates the belief of what is right or what is wrong in the animal husbandry and preslaughter practices (Cembalo et al., 2016). In our results, concerned consumers were mostly female, had a high school or university degree, were aged about 31 years to 45 years old (followed by 18-30 years old), and lived in the city. They were less influenced by emotional arguments about AW or the effect of regulations and were more affected by market demands and available information. In that sense, they were more analytical and realistic with respect to AW compared with ethical consumers. These consumers emphasized there is not enough information about AW in Mexico, that the market is not offering trustworthy WFP, and that farmers should be subsidized. Overall, our results about concerned consumers agreed with those of Bock and van Leeuwen (2005), who analyzed many studies in the EU during the past 10 years and found that many consumers are concerned about AW, especially in the United Kingdom. 
Our study provides further evidence that Mexican consumers do not have enough information regarding AW. Hence, they should receive material information to consider welfare innovations before buying products. Many companies that produce meat, milk, and eggs in Mexico are beginning to develop certification systems for AW due to the increased demand from supermarket chains. Initially, those demands were for imports, but national producers and cooperatives are beginning to satisfy the demand. In the global market, certain branded products or products obtained under voluntary certification schemes are present in Europe (i.e., Freedom Food in the United Kingdom, Deutscher Tierschutzbund in Germany, and Bedre Dyrevelford in Denmark), North America (i.e., Animal Welfare Approved, Certified Humane Raised \& Handled, and American Humane Certified), and Oceania (i.e., Humane Choice True Free Range and Royal Society for the Prevention of Cruelty to Animals or RSPCA -approved farming in Australia, Pig Care in New Zealand).

\section{Ethical consumers}

The profile of ethical consumers suggested that many Mexican consumers are interested in AW (55\% of all respondents). They are sensitive to concerns about AW, livestock production conditions on farms, and the need for new regulations. They also reported a lack of information about WFP in stores and on product labels (average negative score for the information factor). They were mostly female, lived in urban areas, had a university education, and were aged about 31 years to 45 years old (followed by 18-30 years old). Other researchers have found consumers with important ethical concerns in Belgium (Vermeir \& Verbeke, 2006) and Italy (Di Pasquale et al., 2016; Vecchio \& Annunziata, 2012). The demographic profile of these consumers was very similar to our results: middle-aged men and women with an above-average education and high WTP for WFP (Vanhonacker \& Verbeke, 2009).

Ethical consumption is growing worldwide and is characterized by buying products that have symbolic values. Buying WFP represents empathic human-animal emotions and feelings, in addition to their tangible values (Long \& Murray, 2013). According to Caklová and Ulčák (2014), those who buy these products are characterized by their optimism and their belief that their behavior can help to improve AW. However, we should not confuse optimism with naivety, as the consumers are highly educated and know how to analyze information. They do not accept everything they hear or read about in the media, and they consider rational product features such as quality, price, and convenience, as well as how and where products have been produced (Ladhari \& Tchetgna, 2015). It is possible that this type of consumer has emerged as a consequence of recent changes in global capitalism and the spread of consumer culture (Ariztía et al., 2014). Indeed, ethical consumerism might serve as a form of social control of business and provide incentives for companies to be socially and environmentally responsible (Signori \& Forno, 2016).

The ethical consumers we identified in Mexico expressed a rising concern about purchasing behavior related to AW. Their interest in buying WFP was quite high (73\% of ethical consumers). However, they identified a series of problems that kept them from exercising their ethical preferences, including limited choice, high prices, poor labeling, little-known certification systems, and low governmental presence to guarantee the origin and good practice. Indeed, the use of credible labels allows firms to certify product quality or the presence of specific desirable attributes to create the potential for premiums (Vecchio \& Annunziata, 2015).

In Mexico, these types of products are in short supply and include other attributes apart from AW (i.e., organic labeling). However, the risk of mislabeling or misbranding could jeopardize the potential of this group to improve the future of WFP. An inaccurate label could be worse than no labeling. The American Animal Welfare Institute presented a petition to amend labeling regulations under the Federal Meat Inspection Act and the Poultry Products Inspection (Jones, 2014). This petition stated that the use of AW and environmental stewardship claims was approved with little or no supporting evidence from producers. Labeling guidance offers an impractical and inadequate 
solution, as it is impossible to convey complex, multifaceted concepts such as AW and environmental sustainability on product labels.

The current labeling systems result in misleading and deceptive labeling, considered product "misbranding," under current rules. This misbranding frustrates consumers in their attempts to identify meat products that are consistent with their values. Moreover, farmers who invest resources in raising animals under improved welfare and environmental conditions are damaged by producers who are allowed to make value-added claims while merely employing standard production practices. Preventing this misbranding can be accomplished by requiring independent third-party certification of AW and environmental stewardship claims. Third-party certification was supported by nearly $90 \%$ of American consumers responding to a recent survey on meat labeling.

\section{Conclusions}

The results showed that Mexican consumers can be segmented based on how they perceive AW and their WTP for WFP. The MVA suggested there are three clusters or consumer profiles we named "skeptical," "concerned," and "ethical," which explained the associations among AW attitudes, some demographic variables, and WTP for WFP. The respondents had a high level of empathy for animal needs and had a good working knowledge of the living conditions of farm animals. The consumers also demanded more information and more regulations about AW.

The majority of Mexican consumers in all profiles said they were willing to pay more for properly certified WFP. A final interesting question for future research concerns the transition of consumers from one segment to another. The profiles of skeptical, concerned, and ethical consumers suggest that consumers may move in certain directions: from skeptical to concerned, and from concerned to ethical.

For researchers, industry, farmers, and governmental and nongovernmental organizations concerned with moving toward welfare-friendly policies, it is necessary to understand the consumer attitudes about AW that provide the basis for consumption decisions. Results from this study may be useful to include AW as an extrinsic quality attribute of animal food products in Mexico and to define a market-oriented strategy including AW. In this context, we need to develop a reliable and effective labeling system to properly inform consumers about welfare conditions at the farm level. This system should be accompanied by a system to compensate producers who invest resources in raising animals under improved welfare and environmental conditions. At the same time, education and training programs should include aspects of AW with proper informative campaigns using powerful marketing tools to create an educated and well-informed public who will buy products consistent with their values. All of these efforts will require third-party certification to avoid incorrect labeling that frustrates consumer expectations.

\section{Acknowledgments}

Many thanks to Maciel Estrada Chavero for the help during field work. Also, we thank the supermarket chains (specially for Superama "Providencia") for allowing us to carry out the questionnaire. G. C. Miranda-de la Lama and A. A. Rayas-Amor are members of the National Research System of the National Council on Science and Technology.

\section{Funding}

This work was supported by PRODEP (Programa para el Desarrollo Profesional Docente) Grants 103.5/13/8925 UAM-PTC-417 lead by G.C. Miranda-de la Lama. 


\section{References}

Amos, N., \& Sullivan, R. (2017).The business benchmark on farm animal welfare 2016 Report. Business benchmark on farm animal welfare, BBFAW, London, UK. Accessed on 15 June 2017. Retrieved from https://www.bbfaw.com/ media/1450/bbfaw-2016-report.pdf.

Ariztía, T., Kleine, D., Maria das Graças, S. L., Agloni, N., Afonso, R., \& Bartholo, R. (2014). Ethical consumption in Brazil and Chile: Institutional contexts and development trajectories. Journal of Cleaner Production, 63, 84-92.

Atkin, T., \& Thach, L. (2012). Millennial wine consumers: Risk perception and information search. Wine Economy Policy, 1(1), 54-62.

Barber, N., Goodman, R. J., \& Goh, B. K. (2011). Restaurant consumers repeat patronage: Service quality concern. International Journal of Hospitality Management, 30(2), 329-336.

Basha, M. B., Mason, C., Shamsudin, M. F., Hussain, H. I., \& Salem, M. A. (2015). Consumers attitude towards organic food. Procedia Economics and Finance, 31, 444-452.

Bergman, S. M., Fearrington, M. E., Davenport, S. W., \& Bergman, J. Z. (2011). Millennials, narcissism, and social networking: What narcissists do on social networking sites and why. Personality and Individual Differences, 50(5), 706-711.

Bock, B, \& van Leeuwen, F. (2005). Socio-political and market developments of animal welfare schemes. In Roex, J. \& Miele, M(Eds.), Farm animal welfare concerns, consumers, retailers and producers - WelfareQuality ${ }^{\varpi}$ reports no.1, pp. 115-167. Cardiff University.

Brown, H. S., \& Vergragt, P. J. (2016). From consumerism to wellbeing: Toward a cultural transition? Journal of Cleaner Production, 132(20), 308-317.

Caklová, K., \& Ulčák, Z. (2014). Organic meat consumers and their awareness of animal welfare as reflected by purchase preferences. In Book of proceedings: Fifth International Scientific Agricultural Symposium "Agrosym 2014," Jahorina, Bosnia and Herzegovina, October 23-26, 2014 (pp. 958-964). Lukavica, Bosnia and Herzegovina: Faculty of Agriculture, University of East Sarajevo.

Cembalo, L., Caracciolo, F., Lombardi, A., Del Giudice, T., Grunert, K. G., \& Cicia, G. (2016). Determinants of individual attitudes toward animal welfare-friendly food products. Journal of Agricultural and Environmental Ethics, 29(2), 237-254.

COESPO. (2015). El Cambio Demográfico como Impulsor del Desarrollo. Consejo Estatal de Población. Toluca, México: Gobierno del Estado de México. Retrieved from http://coespo.edomex.gob.mx/sites/coespo.edomex.gob.mx/files/ files/PPEM_final.pdf

Dawkins, M. S. (2017). Animal welfare and efficient farming: Is conflict inevitable? Animal Production Science, 57(2), 201-208.

Di Pasquale, J., Nannoni, E., Adinolfi, F., Del Duca, I., Capitanio, F., Sardi, L., .. Martelli, G. (2016). A case-study on profiling Italian consumers of animal-friendly foods. Italian Journal of Animal Science, 15(2), $294-302$.

Eden, S., Bear, C., \& Walker, G. (2008). The sceptical consumer? Exploring views about food assurance. Food Policy, 33 (6), 624-630.

EFSA (2007). Attitudes of EU citizens towards Animal Welfare. Special Eurobarometer 270/ Wave 66.1 - TNS Opinion \& Social. European Commission, 82.

Faucitano, L., Martelli, G., Nannoni, E., \& Widowski, T. (2017). Fundamentals of animal welfare in meat animals and consumer attitudes to animal welfare. In P. P. Purslow (Ed.), New aspects of meat quality: From genes to ethics (pp. 537-568). Sawston, United Kingdom: Woodhead Publishing.

Frank, D., Oytam, Y., \& Hughes, J. (2017). Sensory perceptions and new consumer attitudes to meat. In P. P. Purslow (Ed.), New aspects of meat quality: From genes to ethics (pp. 537-568). Sawston, United Kingdom: Woodhead Publishing.

Gallo, C. B., \& Huertas, S. M. (2016). Main animal welfare problems in ruminant livestockduring preslaughter operations: A South American view. Animal, 10(2), 357-364.

Gasca, J, \& Torres, F. (2014). El control corporativo de la distribución de alimentos en méxico. Revista Problemas Del Desarrollo, 176(1), 133-155.

Gómez-Corona, C., Escalona-Buendía, H. B., García, M., Chollet, S., \& Valentin, D. (2016). Craft vs. industrial: Habits, attitudes and motivations towards beer consumption in Mexico. Appetite, 96, 358-367.

Grewal, R., Mehta, R., \& Kardes, F. R. (2000). The role of the social-identity function of attitudes in consumer innovativeness and opinion leadership. Journal of Economic Psychology, 21(3), 233-252.

Grolleau, G., \& Caswell, J. A. (2006). Interaction between food attributes in markets: The case of environmental labelling. Journal of Agricultural and Resource Economics, 31(3), 471-484.

Harper, G. C., \& Makatouni, A. (2002). Consumer perception of organic food production and farm animal welfare. British of Food Journal, 104(3/4/5), 287-299.

INEGI. (2011). Censo de población y vivienda 2010. Instituto Nacional de Estadística y Geografía.Retrieved from www.inegi.org.mx/sistemas/consulta_resultados/iter2010.aspx?c=27329\&s=est.

Javalgi, R. R. G., \& Grossman, D. A. (2016). Aspirations and entrepreneurial motivations of middle-class consumers in emerging markets: The case of India. International Business Review, 25(2), 657-667. 
Jones, D. (2014). Petition: To amend labeling regulations under the Federal Meat Inspection Act and the Poultry Products Inspection Act to require third-party certification for the approval of animal welfare and environmental stewardship claims. Retrieved from https://www.fsis.usda.gov/wps/wcm/connect/5bdab0ca-8072-480b-9bd9c9bc04b56531/Petition-AWI-Labeling-0514.pdf?MOD=AJPERES.

Ladhari, R., \& Tchetgna, N. M. (2015). The influence of personal values on Fair Trade consumption. Journal of Cleaner Production, 87, 469-477.

Laroche, M., Bergeron, J., \& Barbaro-Forleo, G. (2001). Targeting consumers who are willing to pay more for environmentally friendly products. Journal of Consumer Marketing, 18(6), 503-520.

Long, M. A., \& Murray, D. L. (2013). Ethical consumption, values convergence/divergence and community development. Journal of Agricultural and Environmental Ethics, 26(2), 351-375.

Mazas, B., Fernández-Manzanal, M. R., Zarza, F. J., \& María, G. A. (2013). Development and validation of a scale to assess students' attitude towards animal welfare. International Journal of Science Education, 35(11), 1775-1799.

McCormick, K. (2016). Celebrity endorsements: Influence of a product-endorser match on Millennials attitudes and purchase intentions. Journal of Retailing Consumer Services, 32, 39-45.

Miranda-de la Lama, G. C., Estévez-Moreno, L. X., Sepúlveda, W. S., Estrada-Chavero, M. C., Rayas-Amor, A. A., Villarroel, M., \& María, G. A. (2017). Mexican consumers' perceptions and attitudes towards farm animal welfare and willingness to pay for welfare friendly meat products. Meat Science, 125, 106-113.

Miranda-de la Lama, G. C., Leyva, I. G., Barreras-Serrano, A., Pérez-Linares, C., Sánchez-López, E., María, G. A., \& Figueroa-Saavedra, F. (2012). Assessment of cattle welfare at a commercial slaughter plant in the northwest of Mexico. Tropical Animal Health and Production, 44(3), 497-504.

Miranda-de la Lama, G. C., Sepúlveda, W. S., Villarroel, M., \& María, G. A. (2011). Livestock vehicle accidents in Spain: Causes, consequences, and effects on animal welfare. Journal of Applied Animal Welfare Science, 14(2), 109123.

Miranda-de la Lama, G. C., Sepúlveda, W. S., Villarroel, M., \& María, G. A. (2013). Attitudes of meat retailers to animal welfare in Spain. Meat Science, 95(3), 569-575.

Mulder, M., \& Zomer, S. (2017). Dutch consumers' willingness to pay for broiler welfare. Journal of Applied Animal Welfare Science, 20(2), 137-154.

Newbold, K. B., \& Scott, D. M. (2017). Driving over the life course: The automobility of Canada's millennial, generation X, baby boomer and greatest generations. Travel Behaviour and Society, 6, 57-63.

Pardío, V., Martínez, D., Flores, A., Romero, D., Suárez, V., López, K., \& Uscanga, R. (2012). Human health risk of dietary intake of organochlorine pesticide residues in bovine meat and tissues from Veracruz, Mexico. Food Chemistry, 135, 1873-1893

Pomarici, E., \& Vecchio, R. (2014). Millennial generation attitudes to sustainable wine: An exploratory study on Italian consumers. Journal of Cleaner Production, 66, 537-545.

Popkin, B. M. (2014). Nutrition, agriculture and the global food system in low and middle- income countries. Food Policy, 47, 91-96.

Robbins, J. A., Franks, B., Weary, D. M., \& von Keyserlingk, M. A. G. (2016). Awareness of ag-gag laws erodes trust in farmers and increases support for animal welfare regulations. Food Policy, 61, 121-125.

Sato, P., Hötzel, M. J., \& von Keyserlingk, M. A. (2017). American citizens' views of an ideal pig farm. Animals, 7(8), 64.

Scholten, M. T., De Boer, I. J. M., Gremmen, B., \& Lokhorst, C. (2013). Livestock farming with care: Towards sustainable production of animal-source food. NJAS-Wageningen Journal of Life Sciences, 66, 3-5.

Sepúlveda, W., Maza, M. T., \& Mantecón, A. R. (2008). Factors that affect and motivate the purchase of qualitylabelled beef in Spain. Meat Science, 80(4), 1282-1289.

Signori, S., \& Forno, F. (2016). Closing the attitude-behaviour gap: The case of solidarity purchase groups. Agriculture and Agricultural Science Procedia, 8, 475-481.

Teisl, M. F., Rubin, J., \& Noblet, C. L. (2008). Non-dirty dancing? Interactions between eco-labels and consumers. Journal of Economic Psychology, 29(2), 140-159.

Thach, E. C., \& Olsen, J. E. (2006). Market segment analysis to target young adult wine drinkers. Agribusiness, 22(3), 307-322.

Thøgersen, J., De Barcellos, M. D., Perin, M. G., \& Zhou, Y. (2015). Consumer buying motives and attitudes towards organic food in two emerging markets: China and Brazil. International Marketing Review, 32(3/4), 389-413.

Toma, L., Stott, A. W., Revoredo-Giha, C., \& Kupiec-Teahan, B. (2012). Consumers and animal welfare. A comparison between European Union countries. Appetite, 58(2), 597-607.

Vargas-Bello-Pérez, E., Miranda-de la Lama, G. C., Teixeira, D. L., Enríquez-Hidalgo, D., Tadich, T., \& Lensink, J. (2017). Farm Animal Welfare Influences on Markets and Consumer Attitudes in Latin America: The Cases of Mexico, Chile and Brazil. Journal of Agricultural and Environmental Ethics, 30(5), 697-713.

Vanhonacker, F., \& Verbeke, W. (2009). Buying higher welfare poultry products? Profiling Flemish consumers who do and do not. Poultry Science, 88(12), 2702-2711.

Vanhonacker, F., \& Verbeke, W. (2014). Public and consumer policies for higher welfare food products: Challenges and opportunities. Journal of Agricultural and Environmental Ethics, 27(1), 153-171. 
Vecchio, R., \& Annunziata, A. (2012). Italian consumer awareness of layer hens' welfare standards: A cluster analysis. International Journal of Consumer Studies, 36(6), 647-655.

Vecchio, R., \& Annunziata, A. (2015). Willingness-to-pay for sustainability-labelled chocolate: An experimental auction approach. Journal of Cleaner Production, 86, 335-342.

Velarde, A, \& Dalmau, A. (2012). Animal welfare assessment at slaughter in europe: moving from inputs to outputs. Meat Science, 92(3), 244-251.

Verain, M. C., Sijtsema, S. J., \& Antonides, G. (2016). Consumer segmentation based on food-category attribute importance: The relation with healthiness and sustainability perceptions. Food Quality and Preference, 48, 99-106.

Verbeke, W., \& Viaene, J. (1999). Beliefs, attitude and behaviour towards fresh meat consumption in Belgium: Empirical evidence from a consumer survey. Food Quality and Preference, 10(6), 437-445.

Vermeir, I., \& Verbeke, W. (2006). Sustainable food consumption: Exploring the consumer "attitude-Behavioral intention" gap. Journal of Agricultural and Environmental Ethics, 19(2), 169-194.

Young, M. E., \& McCoy, A. W. (2016). Millennials and chocolate product ethics: Saying one thing and doing another. Food Quality and Preference, 49, 42-53.

Zhllima, E., Imami, D., \& Canavari, M. (2015). Consumer perceptions of food safety risk: Evidence from a segmentation study in Albania. Journal of Integrative Agriculture, 14(6), 1142-1152. 